\title{
Sistem Pakar Diagnosa Penyakit Gizi Buruk Pada Balita Dengan Metode Certainty Factor
}

\author{
Chandra Kirana*1, Lukas Tommy ${ }^{2}$, M.Indra Wijaya ${ }^{3}$ \\ ${ }^{1,2}$ STMIK Atma Luhur; Jl. Jend. Sudirman Selindung Lama Pangkalpinang, Tlp (0717)433506 \\ Jurusan Teknik Informatika, STMIK Atma Luhur, Pangkalpinang \\ e-mail:*1chandra.kirana@atmaluhur.ac.id, ${ }^{2}$ lukastommy@ atmaluhur.ac.id, \\ 31611500029@mahasiswa.atmaluhur.ac.id
}

\begin{abstract}
Abstrak
Masalah gizi merupakan masalah umum dibeberapa negara yang sedang berkembang termasuk indonesia, terutama masalah kekurangan gizi. Salah satu faktor yang mempengaruhi status gizi balita adalah kurangnya pengetahuan orang tua yang diperaktikan dalam pola asuh dan pemberian makanan. Hal ini mendorong peneliti untuk membangun aplikasi sistem pakar yang bertujuan untuk membantu orang tua mendiagnosa penyakit dan gejala gizi buruk pada balita melalui smartphone android, sistem ini dibangun menggunakan bahasa pemograman java dengan alat pembantu yaitu android studio, database MySQL dan PHP. Analisis sistem yang digunakan pada penelitian ini adalah Unified Modelling Language (UML) untuk menggambarkan aplikasi yang akan dibangun. Selanjutnya perhitungan untuk mendiagnosa gejala akan menggunakan metode certainty factor sebagai perhitungan pada aplikasi sistem pakar. Dengan adanya aplikasi ini dapat membantu pengguna khususnya orang tua untuk mengetahui penyakit dan gejala gizi buruk pada balitanya, serta mendapatkan solusi dari penyakit yang di derita.
\end{abstract}

Kata Kunci: Certainty Factor, Android, Gizi Buruk.

\begin{abstract}
Nutrition is a common problem in several developing countries including Indonesia, especially the problem of malnutrition. One of the factors that influence the nutritional status of children under five is the lack of knowledge of parents who are practiced in parenting and feeding. This encourages researchers to build an expert system application that aims to help parents diagnose diseases and symptoms of malnutrition in toddlers through an android smartphone, this system is built using java programming language with helper tools namely android studio, MySQL and PHP databases. The system analysis used in this study is Unified Modeling Language (UML) to describe the application to be built. Furthermore, the calculation to diagnose symptoms will use the certainty factor method as a calculation on the application of an expert system. With this application, it can help users, especially parents, to find out diseases and symptoms of malnutrition in their toddlers, as well as get solutions to the illnesses they are suffering from.
\end{abstract}

Keywords: Certainty Factor, Android, Malnutrition.

\section{PENDAHULUAN}

Gizi merupakan suatu proses penggunaan makanan yang dikonsumsi secara normal melalui proses digesti, absobsi, transportasi, penyimpanan, metabolisme dan pengeluaran zat-zat yang tidak digunakan untuk mempertahankan kehidupan, pertumbuhan dan fungsi normal dari organorgan, serta menghasilkan energi. Untuk mengetahui apakah balita itu mendapatkan gizi yang baik atau tidak, biasa dilakukan dengan pengukuran kadar gizi. Salah satu cara adalah dengan pengukuran tubuh manusia yang dikenal dengan antropometri (ukuran tubuh). Antropometri 
gizi merupakan penilaian status gizi dengan pengukuran dimensi tubuh dan komposisi tubuh dari berbagai tingkat umur dan tingkat gizi[1].

Untuk memudahkan seorang ibu dalam melakukan diagnosis gizi buruk pada balita, maka dibutuhkan sebuah aplikasi khusus untuk menangani permasalahan tersebut. Salah satunya adalah aplikasi sistem pakar, yaitu sebuah sistem yang dihasilkan dari pemikiran seorang ahli atau pakar yang diterapkan pada sebuah program aplikasi komputer, dimana sistem pakar ini merupakan sebuah program Artificial Intelligence (AI) yang menggabungkan basis pengetahuan dengan inference engine. Program ini bertindak atau berfungsi sebagai seorang pakar pada bidang tertentu dalam hal ini adalah ahli tentang kepakaran gizi[1].

Pada indentifikasi sistem usulan peneliti akan menggunakan aplikasi web sebagai server dan android sebagai client, kemudian pada tahap selanjutnya peneliti akan membangun aplikasi sistem pakar yang berfungsi untuk melakukan diagnosa penyakit gizi buruk pada balita sesuai dengan gejala yang telah dipilih oleh pengguna.

Penelitian yang penulis lakukan berkaitan dengan penelitian terdahulu yang telah dilakukan sebelumnya, diantaranya Penelitian dari Annahl Riadi pada tahun 2017 dengan judul "Penerapan Metode Certainty Factor Untuk Sistem Pakar Diagnosa Penyakit Diabetes Melitus Pada RSUD Bumi Panua Kabupaten Pohuwato Menggunakan Metode Certainty Factor" dimana hasil dari penelitian ini adalah sistem pakar ini untuk membantu tenaga medis dan juga penderita Diabetes Melitus, serta memiliki nilai prosentase $80 \%$ terhadap hasil analisa pakar[2]. Penelitian dari Candra Kirana, Harrizkie Arie Pradana dan Rahmat Sulaiman pada tahun 2019 dengan judul "Sistem Diagnosis Penyakit Usus Menggunakan Metode Certainty Factor" dimana hasil dari penelitian ini adalah aplikasi yang dapat membantu dokter, tenaga medis maupun penderita untuk mendiagnosa atau mengetahui penyakit usus dengan tingkat akurasi 99,82\%[3]. Penelitian dari Ricky Hamidi, Hengky Anra dan Helen Sasty Pratiwi pada tahun 2017 dengan judul "Analisis Perbandingan Sistem Pakar Dengan Metode Certainty Factor dan Metode Dempster Shafer Pada Penyakit Kelinci" dimana hasil dari penelitian ini adalah Metode Dempster Shafer mendiagnosis penyakit kelinci di kota Pontianak lebih baik dibandingkan dengan metode Certainty Factor. Tingkat keakuratan hasil diagnosis sistem pakar dengan metode Certainty Factor adalah $80 \%$, sedangkan hasil diagnosis sistem pakar dengan metode Dempster Shafer adalah 85\%[4]. Penelitian dari Stephanie dan Seng Hansun pada tahun 2015 dengan judul "Penerapan Metode Certainty Factror Dalam Sistem Pakar Pendeteksi Resiko Osteoporosis Dan Osteoarthritis" dimana hasil dari penelitian ini adalah sistem ini berhasil di implementasikan dengan presentasi keakuratan $80 \%$ menjadi bukti nyata bahwa diagnose gejala setiap pakar mempengaruhi tingkat keakuratan sIstem[5]. Penelitian dari Bayu Kurniawan, Yustina Retno Wahyu Utami, dan Wawan Laksito Yuly Saptomo pada tahun 2017 dengan judul "Sistem Pakar Diagnosa Penyakit Paru Pada Anak Dengan Metode Certainty Factor" dimana hasil dari penelitian ini adalah sistem ini telah dapat digunakan untuk konsultasi mengenai penyakit paru-paru pada anak sehingga selaku orang tua lebih cepat dalam melakukan pencegahan sejak dini[6].

\section{METODE PENELITIAN}

\subsection{Model Pengembangan Perangkat Lunak}

Pada penelitian ini, peneliti menggunakan model prototype sebagai model pengembangan perangkat lunak, dimana model ini dapat membantu proses pengembangan sistem yang akan dibuat dikarenakan model ini dapat dievaluasi dan dapat di ubah lagi menyesuaikan kebutuhan. 


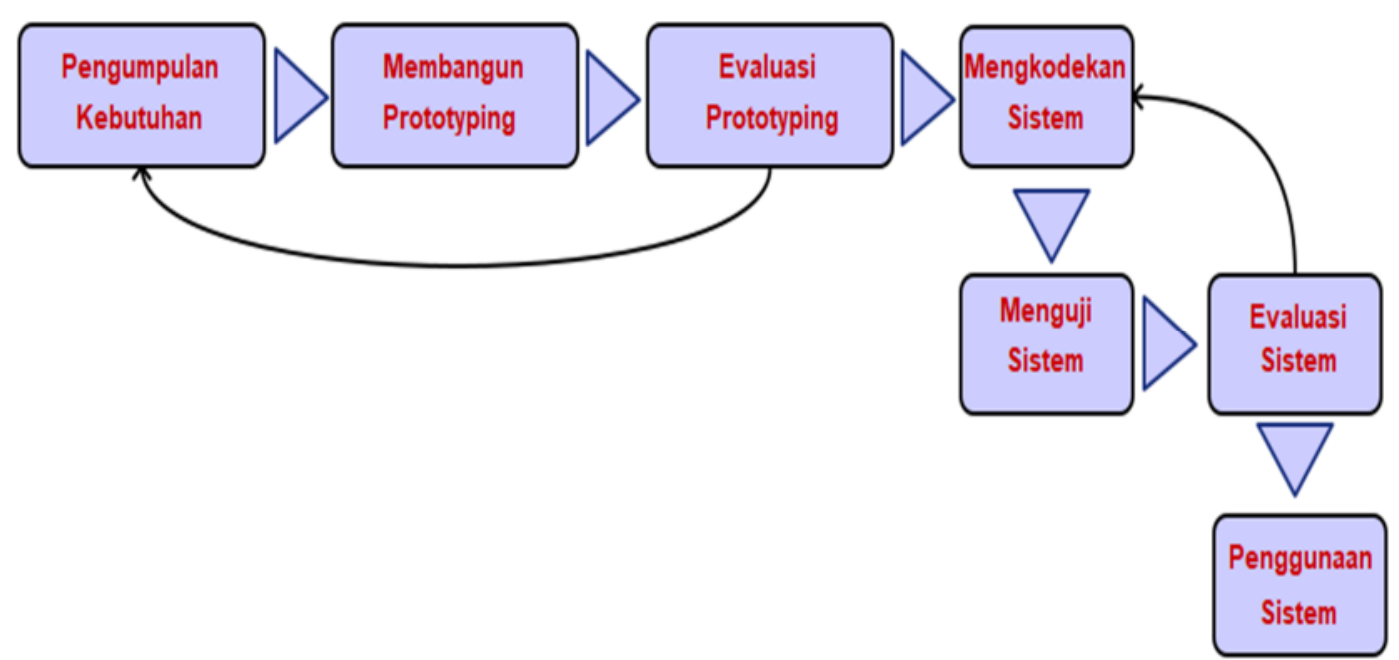

\section{Gambar 1. Tahapan Model Prototype}

\section{2 Metode Certainty Factor}

Certainty Factor (CF) merupakan sebuah metode yang diusulkan oleh Shortliffe dan Buchanan pada 1975 untuk mengakomodasi ketidak pastian pemikiran (inexact reasoning) seorang pakar. Seorang pakar contohnya dokter sering menganalisis informasi dengan ungkapan "mungkin", "kemungkinan besar", "hampir pasti". Sehingga dengan adanya metode Certainty Factor ini dapat menggambarkan tingkat keyakinan seorang pakar terhadap masalah yang sedang dihadapi[7].

Ada dua cara dalam mendapatkan tingkat keyakinan (CF) dari sebuah rule, yaitu[8]:

1. Dengan cara mewancarai seorang pakar.

Nilai $\mathrm{CF}($ rule) didapat dari interpretasi "term" dari pakar, yang diubah menjadi nilai CF tertentu sesuai tabel berikut[8].

Tabel 1. Tabel Uncertain Term

\begin{tabular}{lc}
\hline \multicolumn{1}{c}{ Uncertain Term } & CF \\
\hline Definitely not (pasti tidak) & $-1,0$ \\
\hline Almost certainly not (hampir pasti tidak) & $-0,8$ \\
\hline Probably not (kemungkinan besar tidak) & $-0,6$ \\
\hline Maybe not (mungkin tidak) & $-0,4$ \\
\hline Unknown (tidak tahu) & $-0,2$ sampai 0,2 \\
\hline Maybe (mungkin) & 0,4 \\
\hline Probably (kemungkinan besar) & 0,6 \\
\hline Almost certainly (hampir pasti) & 0,8 \\
\hline Definitely (pasti) & 1,0 \\
\hline
\end{tabular}

Contoh :

Pakar : Jika tidak haid maka 'kemungkinan besar' (probably) 
penyakitnya adalah hamil.

Rule $\quad$ : IF tidak haid THEN penyakit $=$ hamil $(\mathrm{CF}=0,6)$. sama[12]:

Kombinasi dua buah rule dengan evidence berbeda (E1 dan E2), tetapi hipotesisnya

\begin{tabular}{|c|c|c|}
\hline IF E1 THEN & Rule & $\mathrm{CF}(\mathrm{H}, \mathrm{E} 1)=\mathrm{CF} 1$ \\
\hline $\mathrm{H}$ & & $=\mathrm{C}(\mathrm{E} 1) \times \mathrm{CF}($ Rule 1) \\
\hline IF E2 THEN & Rule & $\mathrm{CF}(\mathrm{H}, \mathrm{E} 2)=\mathrm{CF} 2$ \\
\hline $\mathrm{H}$ & 2 & $=\mathrm{C}(\mathrm{E} 2) \times \mathrm{CF}($ Rule 2$)$ \\
\hline
\end{tabular}

\section{3 Perancangan Sistem}

a. Dalam penelitian ini rancangan sistem digambarkan menggunakan tools UML. Berikut rancangan sistem didalam penelitian ini:

1. Usecase Diagram

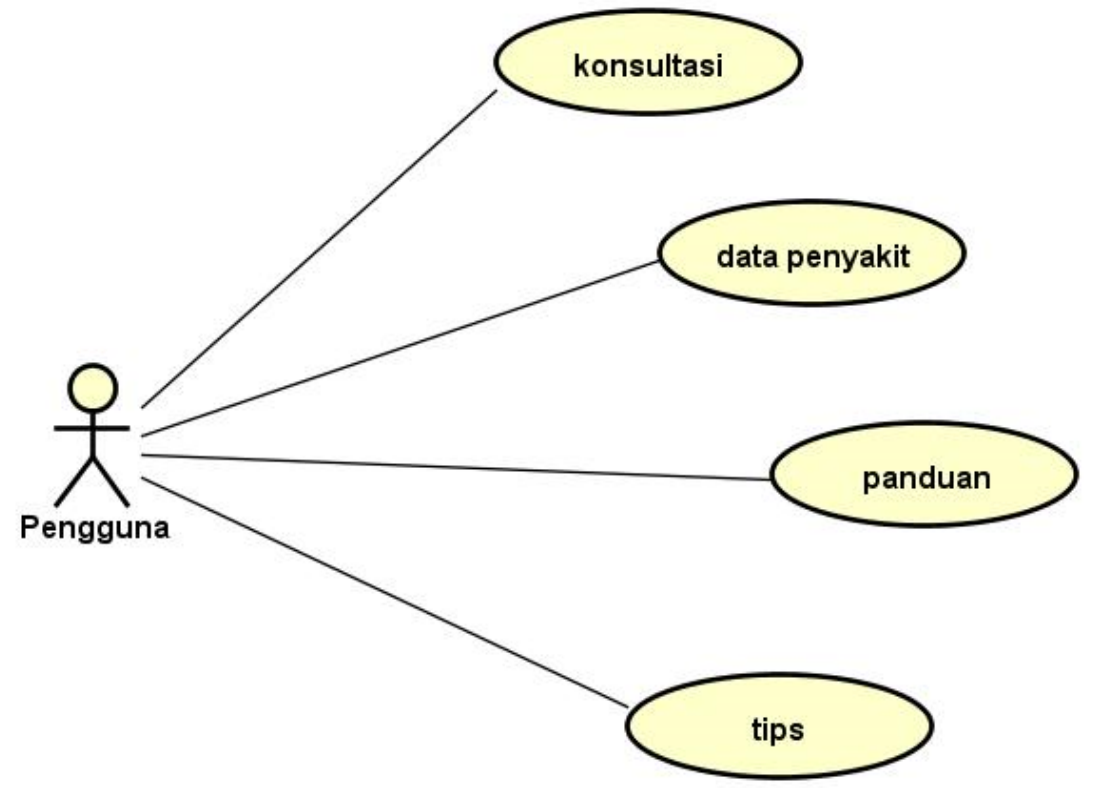

Gambar 2. Usecase Diagram

Gambar 2 menjelaskan aktifitas apasaja yang dapat dilakukan oleh pengguna melalui aplikasi yang telah dibuat menggunakan aplikasi android.

2. Class Diagram

Class Diagram digunakan untuk menampilkan struktur sistem dari kelas-kelas yang ada pada sistem pakar. Model class diagram dapat dilihat pada gambar 2 . 


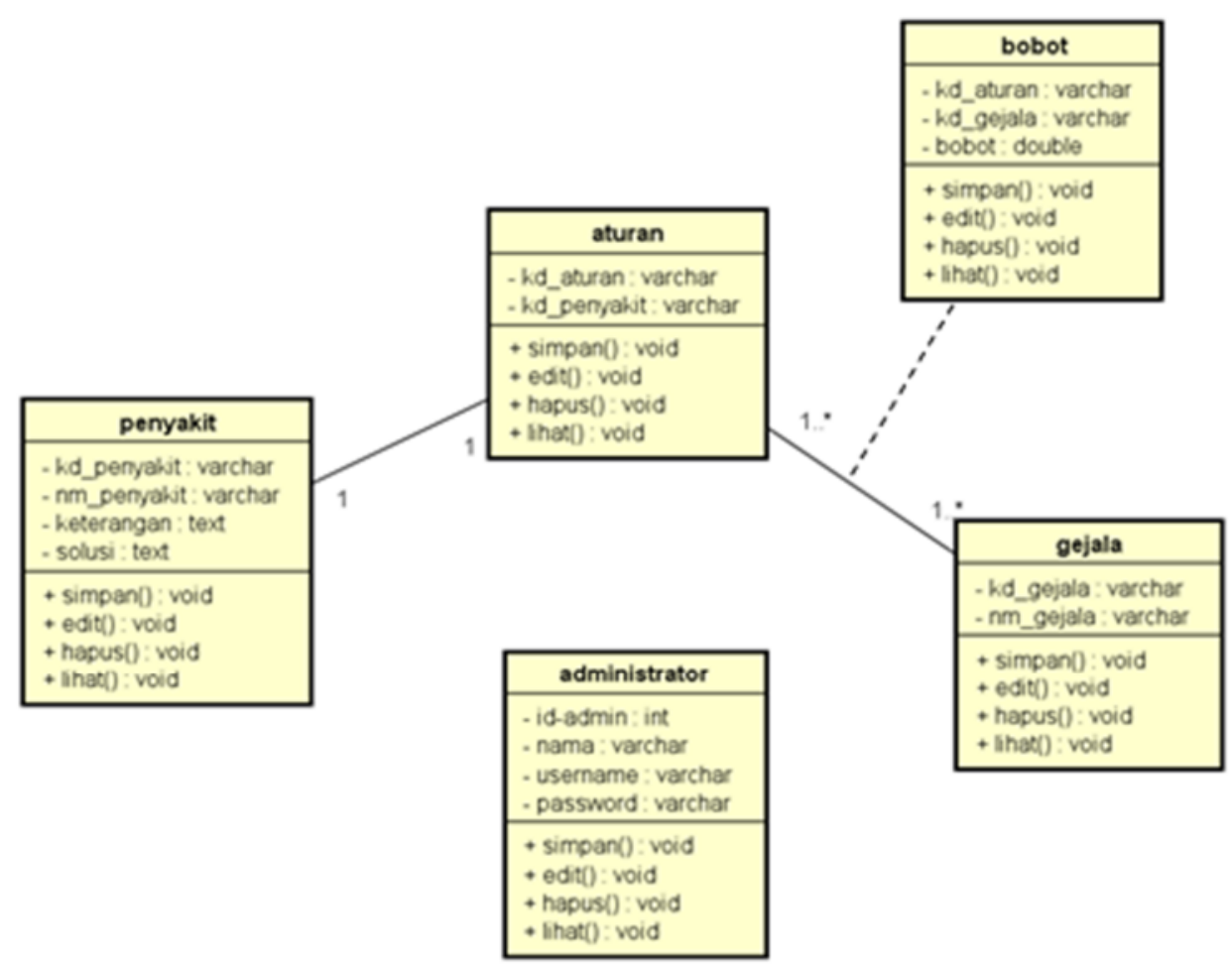

Gambar 3. Class Diagram

\section{HASIL DAN PEMBAHASAN}

\subsection{Analisis Metode Certainty Factor}

Pada tahapan ini dilakukan penentuan data relasi penyakit dan gejala, nilai kepastian, dan perhitungan metode certainty factor.

\subsubsection{Penentuan Relasi Penyakit dan Gejala}

Data penyakit dan gejala didapatkan dari studi umum dari buku yang terkait dengan penyakit gizi buruk pada balita. Tabel 3.1 adalah tabel relasi penyakit dan gejala pada sistem pakar diagnosa penyakit gizi buruk pada balita.

Tabel 2. Tabel Relasi Penyakit dan Gejala

\begin{tabular}{|c|c|c|c|c|c|c|c|c|c|c|}
\hline \multirow[b]{2}{*}{ Gejala } & \multicolumn{10}{|c|}{ Penyakit } \\
\hline & $\begin{array}{l}\mathrm{P}- \\
01\end{array}$ & $\begin{array}{l}\mathrm{P}- \\
02\end{array}$ & $\begin{array}{l}\mathrm{P}- \\
03\end{array}$ & $\begin{array}{l}\text { P- } \\
04\end{array}$ & $\begin{array}{l}\mathrm{P}- \\
05\end{array}$ & $\begin{array}{l}\text { P- } \\
06\end{array}$ & $\begin{array}{l}\text { P- } \\
07\end{array}$ & $\begin{array}{l}\text { P- } \\
08\end{array}$ & $\begin{array}{l}\text { P- } \\
09 \\
\end{array}$ & $\begin{array}{l}\text { P- } \\
10\end{array}$ \\
\hline G-01 & $\checkmark$ & & & & & & & & & \\
\hline G-02 & $\checkmark$ & & & & & & & & & \\
\hline G-03 & $\checkmark$ & & & & & & & & & \\
\hline G-04 & & $\checkmark$ & & & & & & & & \\
\hline
\end{tabular}




\begin{tabular}{|c|c|c|c|c|c|c|c|c|c|c|}
\hline \multirow{2}{*}{ Gejala } & \multicolumn{10}{|c|}{ Penyakit } \\
\hline & $\begin{array}{l}\text { P- } \\
01\end{array}$ & $\begin{array}{l}\mathrm{P}- \\
02\end{array}$ & $\begin{array}{l}\mathrm{P}- \\
03\end{array}$ & $\begin{array}{l}\mathrm{P}- \\
04\end{array}$ & $\begin{array}{l}\mathrm{P}- \\
05\end{array}$ & $\begin{array}{l}\text { P- } \\
06\end{array}$ & $\begin{array}{l}\text { P- } \\
07\end{array}$ & $\begin{array}{l}\text { P- } \\
08\end{array}$ & $\begin{array}{l}\text { P- } \\
09\end{array}$ & $\begin{array}{l}\text { P- } \\
10\end{array}$ \\
\hline G-05 & & $\checkmark$ & & & & & & & & \\
\hline G-06 & & $\checkmark$ & & & & & & & & \\
\hline G-07 & & $\checkmark$ & & & & & & & & \\
\hline G-08 & & & $\checkmark$ & & & $\checkmark$ & & $\checkmark$ & $\checkmark$ & $\checkmark$ \\
\hline G-09 & & & $\checkmark$ & & & & & & & \\
\hline G-10 & & & $\checkmark$ & & & & & & & \\
\hline G-11 & & & $\checkmark$ & $\checkmark$ & & & & & & \\
\hline G-12 & & & & $\checkmark$ & & & & & & \\
\hline G-13 & & & & $\checkmark$ & & & & & & \\
\hline G-14 & & & & $\checkmark$ & & & & & & \\
\hline G-15 & & & & & $\checkmark$ & & $\checkmark$ & & & \\
\hline G-16 & & & & & $\checkmark$ & & & & & \\
\hline G-17 & & & & & $\checkmark$ & & & & & \\
\hline G-18 & & & & & $\checkmark$ & $\checkmark$ & & & $\checkmark$ & \\
\hline G-19 & & & & & & $\checkmark$ & & & & \\
\hline G-20 & & & & & & $\checkmark$ & & & & \\
\hline G-21 & & & & & & & $\checkmark$ & & & \\
\hline G-22 & & & & & & & & $\checkmark$ & $\checkmark$ & \\
\hline G-23 & & & & & & & & $\checkmark$ & & \\
\hline G-24 & & & & & & & & $\checkmark$ & & \\
\hline G-25 & & & & & & & & & $\checkmark$ & \\
\hline G-26 & & & & & & & & & & $\checkmark$ \\
\hline G-27 & & & & & & & & & & $\checkmark$ \\
\hline G-28 & & & & & & & & & & $\checkmark$ \\
\hline
\end{tabular}

Keterangan Tabel 2, meliputi :

1. Data Gejala 


\begin{tabular}{|c|c|c|}
\hline & G-01 & : Balita terlihat sangat kurus \\
\hline & G-02 & : Kulit pada balita sangat tipis \\
\hline & G-03 & : Tulang tangan, kaki dan dada balita sangat jelas dan menonjol \\
\hline & G-04 & : Kulit, bibir dan kelopak mata balita sangat pucat \\
\hline & G-05 & : Rambut balita menjadi mudah dicabut, rusak dan berwarna kuning \\
\hline & G-06 & : Perut balita mengalami pembesaran \\
\hline & G-07 & : Pembengkakan pada kaki dan perut \\
\hline & G-08 & : Balita sering tidur dan tidak mau beraktifitas \\
\hline & G-09 & : Kulit terlihat pucat atau kekuningan \\
\hline & G-10 & : Tangan dan kaki balita terasa dingin \\
\hline & G-11 & : Balita sering menangis \\
\hline & G-12 & : Bengkak pada leher balita \\
\hline & G-13 & : Mata melotot (seperti mau keluar) \\
\hline & G-14 & : Keringat berlebihan \\
\hline & G-15 & : Balita sulit berjalan \\
\hline & G-16 & : Keringat berlebihan \\
\hline & G-17 & : Balita sulit berbicara \\
\hline & G-18 & : Kelumpuhan pada kaki balita \\
\hline & G-19 & : Kulit balita bersisik dan tebal pada saat terkena sinar matahari \\
\hline & G-20 & : Sering rewel \\
\hline & G-21 & : Kaki balita membengkak \\
\hline & G-22 & : Berat badan menurun \\
\hline & G-23 & : Sering muntah-muntah \\
\hline & G-24 & : Balita mengalami borok dikulit \\
\hline & G-25 & : Perut balita mengalami pembesaran \\
\hline & G-26 & : Kerontokan pada rambut balita \\
\hline & G-27 & : Kering pada kulit balita \\
\hline & G-28 & : Balita mengalami sesak nafas \\
\hline 2. & \multicolumn{2}{|c|}{ Data Penyakit } \\
\hline & P-01 & : Marasmus \\
\hline & P-02 & : Kwashiorkor \\
\hline & P-03 & : Anemia \\
\hline & P-04 & : Gondok \\
\hline
\end{tabular}




\begin{tabular}{lll}
\hline P-05 & $:$ & Beri-Beri \\
\hline P-06 & $:$ & Pellagra \\
\hline P-07 & $:$ & Rakhitis \\
\hline P-08 & $:$ & Cachexia \\
\hline P-09 & $:$ & Gagal Hati \\
\hline P-10 & $:$ & Edema
\end{tabular}

\subsubsection{Nilai Kepastian}

Berdasarkan relasi data penyakit dan gejala, berikut adalah nilai kepastian setiap relasi yang didapatkan dari wawancara berupa kuisioner dengan dokter spesialis anak.

Tabel 3 Nilai CF Gejala Gizi Buruk Pada Balita

\begin{tabular}{|c|c|c|c|}
\hline No. & Nama Penyakit & Gejala & $\mathbf{C F}$ \\
\hline \multirow{3}{*}{1.} & \multirow{3}{*}{ Marasmus } & Balita terlihat sangat kurus & 0.8 \\
\hline & & Kulit pada balita sangat tipis & 0.8 \\
\hline & & $\begin{array}{l}\text { Tulang tangan, kaki dan dada balita } \\
\text { sangat jelas dan menonjol }\end{array}$ & 0.4 \\
\hline \multirow{4}{*}{2.} & \multirow{4}{*}{ Kwashiorkor } & $\begin{array}{l}\text { Kulit, bibir dan kelopak mata balita sangat } \\
\text { pucat }\end{array}$ & 0.8 \\
\hline & & $\begin{array}{l}\text { Rambut balita menjadi mudah dicabut, } \\
\text { rusak dan berwarna kuning }\end{array}$ & 0.6 \\
\hline & & Perut balita mengalami pembesaran & 0.6 \\
\hline & & Pembekakan pada kaki dan perut & 0.8 \\
\hline \multirow{4}{*}{3.} & \multirow{4}{*}{ Anemia } & $\begin{array}{l}\text { Balita sering tidur dan tidak mau } \\
\text { beraktifitas }\end{array}$ & 0.6 \\
\hline & & Kulit terlihat pucat atau kekuningan & 0.4 \\
\hline & & Tangan dan kaki balita terasa dingin & 0.6 \\
\hline & & Balita sering menangis & 0.8 \\
\hline \multirow{2}{*}{4.} & \multirow{2}{*}{ Gondok } & Bengkak pada leher balita & 0.8 \\
\hline & & Mata melotot (seperti mau keluar) & 0.6 \\
\hline
\end{tabular}


Keringat berlebihan

0.2

\begin{tabular}{|c|c|c|c|}
\hline \multirow{4}{*}{5.} & \multirow{4}{*}{ Beri-Beri } & Balita sulit berjalan & 0.6 \\
\hline & & Keringat berlebihan & 0.6 \\
\hline & & Balita sulit berbicara & 0.2 \\
\hline & & Kelumpuhan pada kaki balita & 0.4 \\
\hline \multirow{4}{*}{6.} & \multirow{4}{*}{ Pellagra } & $\begin{array}{l}\text { Kulit balita bersisik dan tebal pada saat } \\
\text { terkena sinar matahari }\end{array}$ & 0.4 \\
\hline & & Muntah dan diare & 0.6 \\
\hline & & Sering rewel & 0.4 \\
\hline & & $\begin{array}{l}\text { Balita sering tidur dan tidak mau } \\
\text { beraktifitas }\end{array}$ & 0.4 \\
\hline \multirow{2}{*}{7.} & \multirow{2}{*}{ Rakhitis } & Balita sulit berjalan & 0.4 \\
\hline & & Kaki balita membengkak & 0.4 \\
\hline \multirow{4}{*}{8.} & \multirow{4}{*}{ Cachexia } & Berat badan menurun & 0.6 \\
\hline & & Sering muntah-muntah & 0.4 \\
\hline & & Balita mengalami borok dikulit & 0.4 \\
\hline & & $\begin{array}{l}\text { Balita sering tidur dan tidak mau } \\
\text { beraktifitas }\end{array}$ & 0.6 \\
\hline \multirow{4}{*}{9.} & \multirow{4}{*}{ Gagal Hati } & Perut balita mengalami pembesaran & 0.8 \\
\hline & & Muntah dan diare & 0.6 \\
\hline & & $\begin{array}{l}\begin{array}{l}\text { Balita sering tidur dan tidak mau } \\
\text { beraktifitas }\end{array} \\
\end{array}$ & 0.6 \\
\hline & & Sering muntah-muntah & 0.6 \\
\hline & \multirow{4}{*}{ Edema } & $\begin{array}{l}\text { Balita sering tidur dan tidak mau } \\
\text { beraktifitas }\end{array}$ & 0.6 \\
\hline & & Kerontokan pada rambut balita & 0.2 \\
\hline & & Kering pada kulit balita & 0.4 \\
\hline & & Balita mengalami sesak nafas & 0.4 \\
\hline
\end{tabular}




\subsubsection{Perhitungan Metode Certainty Factor}

Kemudian dari nilai-nilai CF tiap relasi yang ada, akan dilakukan perhitungan sesuai dengan gejala yang dipilih. Masing-masing gejala memiliki nilai CF yang digunakan untuk menentukan nilai CF kombinasi. Misalnya dipilih 3 gejala:

1. Balita terlihat sangat kurus

2. Kelemahan pada otot

3. Badan terasa lemas dan cepat lelah

Dari 3 gejala yang telah dipilih akan dicari penyakit apa saja yang berhubungan dan nilai CF setiap gejala pada masing-masing penyakit.

Tabel 4. Penyakit yang Berhubungan Dengan Gejala

\begin{tabular}{|c|c|c|c|}
\hline No. & Gejala yang Dipilih & Penyakit & $\mathbf{C F}$ \\
\hline 1. & Balita terlihat sangat kurus & Marasmus & 0.8 \\
\hline \multirow{3}{*}{2.} & \multirow{3}{*}{$\begin{array}{l}\text { Balita sering tidur dan tidak } \\
\text { mau beraktifitas }\end{array}$} & Anemia & 0.6 \\
\hline & & Pellagra & 0.4 \\
\hline & & Cachexia & 0.6 \\
\hline \multirow{2}{*}{3.} & \multirow{2}{*}{ Keringat berlebihan } & Gondok & 0.2 \\
\hline & & Beri-Beri & 0.6 \\
\hline
\end{tabular}

Pada Tabel 4. diketahui penyakit yang memiliki hubungan dengan gejala yang dipilih adalah :
1. Marasmus
2. Anemia
3. Pellagra
4. Cachexia
5. Gondok
6. Beri-Beri

Pada tabel diatas dapat diketahui juga bahwa nilai CF gejala yang sama pada penyakit yang berbeda tidak selalu sama. Perhitungan dari tiap-tiap penyakit dijabarkan sebagai berikut : 
1. Marasmus

$\begin{array}{lll}\mathrm{CF} & =0,8 & \text { (Gejala G-01) } \\ \text { Hasil Persentase } & =0,8 * 100 \% & \\ & =80 \%\end{array}$

2. Anemia

$$
\begin{array}{lll}
\mathrm{CF} & =0,6 & \text { (Gejala G-08) } \\
\text { Hasil Persentase } & =0,6 * 100 \% & \\
& =60 \%
\end{array}
$$

3. Pellagra-Cachexia

$$
\begin{array}{ll}
\mathrm{CF} & =0,4+0,6 *(1-0,4) \quad(\text { Gejala G-22 dan G-28) } \\
& =0,4+0,6 * 0,6 \quad \\
& =0,4+0,36 \\
& =0,76 \\
\text { Hasil Persentase } & =0,76 * 100 \% \\
& =76 \%
\end{array}
$$

4. Gondok

$$
\begin{array}{lll}
\mathrm{CF} & =0,2 & \text { (Gejala G-14) } \\
\text { Hasil Persentase } & =0,2 * 100 \%
\end{array}
$$

5. Beri-Beri

$$
\begin{array}{lll}
\mathrm{CF} & =0,6 & \text { (Gejala G-16) } \\
\text { Hasil Persentase } & =0,6 * 100 \% \quad \\
& =60 \%
\end{array}
$$

Sehingga dapat disimpulkan penyakit yang diderita dengan kemungkinan tertinggi yaitu Marasmus dengan nilai CF tertinggi yaitu sebesar $80 \%$.

\subsection{User Interface}

Pada indentifikasi sistem usulan peneliti akan menggunakan aplikasi web sebagai server dan android sebagai client, kemudian pada tahap selanjutnya peneliti akan membangun aplikasi sistem pakar yang berfungsi untuk melakukan diagnosa gizi buruk pada balita sesuai dengan gejala yang telah dipilih oleh pengguna. Pertama-tama administrator akan memasukan data penyakit, data gejala dan data aturan penilaian metode certainty factor kedalam web server, selanjutnya pengguna dapat menggunakan aplikasi android untuk menampilkan data-data yang sesuai dengan web server. Selanjutnya pengguna dapat memilih gejala-gejala apa saja yang diderita lalu menekan tombol proses. Data gejala yang telah dipilih kemudian akan dikirimkan ke web server, lalu web server akan memproses gejala yang dikirim menggunakan metode certainty factor. Selanjutnya hasil dari proses perhitungan akan dikirimkan kembali ke aplikasi android pengguna hasil yang dikirimkan berupa nama penyakit yang telah dipilih dan persentase kemungkinannya. 


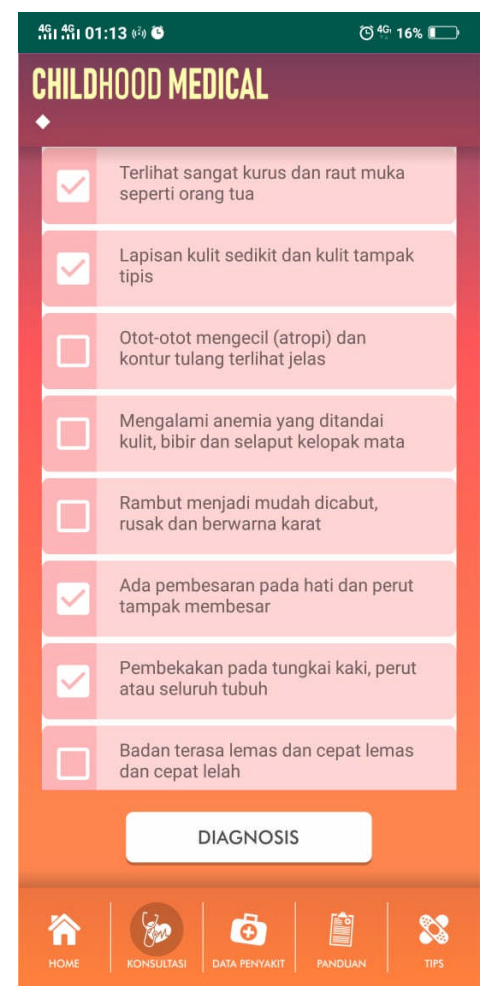

Gambar 4. Tampilan Layar Konsultasi

Gambar 4. Memjelaskan bagaimana seorang pengguna melakukan konsultasi dengan menggunakan aplikasi sistem pakar berbasis android. Pengguna yang ingin melakukan diagnosis penyakit yang dialaminya, maka pengguna dapat menginputkan gejala dengan cara checklist terhadap gejala yang sesuai dengan kondisi yang dialami. Hasil diagnosis dapat dilihat pada gambar 5 .

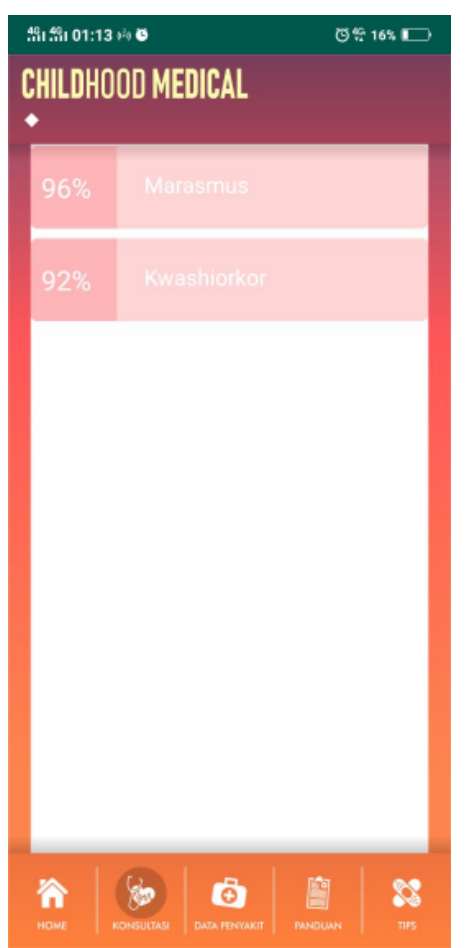

Gambar 5. Tampilan Hasil Diagnosis 
Berdasarkan hasil diagnosis, sistem menampilkan beberapa penyakit yang mempunyai sebuah gejala yang sama, yang didapat berdasarkan aturan dari metode Certainty Factor.

\subsection{Pengujian Sistem}

Pada penelitian ini pengujian sistem dilakukan untuk melihat apakah sistem pakar berbasis android dapat bekerja dengan baik dan sesuai dengan rancangan sistem. Pengujian yang dilakukan menggunakan pengujian BlackBox.

Tabel 5. Pengujian Black Box Android Client

\begin{tabular}{llll}
\hline No. & Fitur yang diuji & Hasil yang diharapkan & Hasil \\
\hline 1. & Pilih menu konsultasi & Masuk ke form konsultasi & Sesuai \\
\hline 2. & $\begin{array}{l}\text { Ceklis gejala dan pilih proses } \\
\text { diagnosis }\end{array}$ & Masuk ke form hasil diagnosis & Sesuai \\
\hline 3. & Pilih penyakit & Masuk ke form detail penyakit & Sesuai \\
\hline 4. & Pilih menu data penyakit & Masuk ke form data penyakit & Sesuai \\
\hline 5. & Pilih penyakit & Masuk ke form detail penyakit & Sesuai \\
\hline 6. & Pilih menu panduan & Masuk ke form panduan & Sesuai \\
\hline 7. & Pilih menu tips & Masuk ke form tips & Sesuai \\
\hline
\end{tabular}

Tabel 6. Pengujian Aplikasi di Smartphone Pengguna

\begin{tabular}{cllcc}
\hline No. & \multicolumn{1}{c}{ Tipe \& Merek HP } & Versi Android & Install & Hasil \\
\hline 1. & Vivo V9 & $8.0($ Oreo) & Berhasil & Berjalan \\
\hline 2. & Samsung Galaxy S8 & 8.0 (Oreo) & Berhasil & Berjalan \\
\hline 3. & Xiaomi Redmi 5 & 7.0 (Nougat) & Berhasil & Gagal \\
\hline 4. & Mi A1 & 9.0 (Pie) & Behasil & Gagal \\
\hline 5. & Xiaomi Note 3 & 5.0 (Lollipop) & Gagal & Gagal \\
\hline 6. & Vivo V7+ & $8.0($ Oreo) & Berhasil & Berjalan \\
\hline 7. & Samsung Galaxy J3 & $8.0($ Oreo) & Berhasil & Berjalan \\
\hline 8. & Xiaomi Pocophone & $9.0($ Pie) & Berhasil & Gagal \\
\hline 9. & Samsung J8 & $8.0($ Oreo) & Berhasil & Berjalan \\
\hline 10. & Vivo V5 & 6.0 (Marshmallow) & Berhasil & Gagal \\
\hline
\end{tabular}

\section{KESIMPULAN}

Berdasarkan analisis dan rancangan sistem yang telah dibuat, penulis mengambil beberapa kesimpulan, diantaranya adalah sistem pakar diagnosis penyakit gizi buruk pada balita dengan menggunakan metode Certainty Factor dapat digunakan untuk mendiagnosis penyakit gizi buruk pada balita. Dilihat dari pengujian yang telah dilakukan menggunakan sistem pakar dengan beberapa gejala dan penyakit didapat nilai kesesuaian sebesar $80 \%$. 


\section{SARAN}

Berdasarkan hasil penelitian yang telah dilakukan, maka penulis memberikan beberapa saran yang dapat dilakukan oleh para peneliti selanjutnya diantaranya:

a. Sistem pakar menggunakan metode Certainty Factor sebaiknya dilakukan kombinasi metode yang lain yang dapat memberikan hasil yang maksimal dan dapat memprediksi faktor ketidakpastian.

b. Untuk mendapatkan hasil yang lebih maksimal, maka sebaiknya dilakukan pengujian yang lebih banyak sehingga hasil yang didapat lebih akurat lagi.

\section{UCAPAN TERIMA KASIH}

Penulis mengucapkan terima kasih kepada STMIK Atma Luhur yang telah memberi dukungan financial terhadap penelitian ini.

\section{DAFTAR PUSTAKA}

[1] Evi D, S, M., Deny, E., dan Novi, A., 2015, Sistem Pakar Diagnosis Gizi Buruk Pada Balita Menggunakan Metode Forward Chaining Di Pukesmas Tinewati, Jurnal Teknik Informatika, STMIK, Tasikmalaya.

[2] Annahl, R., 2017, Penerapan Metode Certainty Factor Untuk Sistem Pakar Diagnosa Penyakit Diabetes Melitus Pada RSUD Bumi Panua Kabupaten Puhuwato Menggunakan Metode Certainty Factor, Jurnal Magister Teknik Informatika Universitas Amikom Yogyakarta, No.2, Vol.11, 1978-8282.

[3] Kirana, C., Pradana, H. A. dan Sulaiman, R., 2019, Sistem Diagnosis Penyakit Usus Menggunakan Metode Certainty Factor, Jurnal Teknik Informatika, STMIK Atma Luhur Pangkalpinang,. Vol. 6, No. 1, 82-94.

[4] Hamidi, R., Anra, H., dan Pratiwi, H. S., 2017, Analisis Perbandingan Sistem Pakar Dengan Metode Certainty Factor dan Metode Dempster Shafer Pada Penyakit Kelinci, Jurnal Sistem dan Teknologi Informasi, No.2, Vol.1, 80-85.

[5] Stephanie dan Seng, H., 2015, Penerapan Metode Certainty Factor Dalam Sistem Pakar Pendeteksi Resiko Osteoporosis Dan Osteoarthritis, Jurnal Teknik Informatika, Universitas Multimedia Nusantara, Tanggerang, No.2, Vol.7, 59-69.

[6] Bayu, K., Yustina, R, W, U., dan Wawan, L, Y, S., 2017, Sistem Pakar Diagnosa Penyakit Paru Pada Anak Dengan Metode Certainty Factor, Jurnal Teknologi Informasi Dan Komunikasi Sinar Nusantara, No.2, Vol.5, 53-60.

[7] Saluky., 2018, Tinjauan Artificial Intelligence Untuk Smart Government, Jurnal Sekolah Teknik Electro dan Informatika, Institut Teknologi Bandung.

[8] Aryu, H, A., M. Tanzil, F., dan Agus, W, W., 2018, Sistem Pakar Diagnosa Penyakit Ibu Hamil Menggunakan Metode Certainty Factor (CF), Jurnal Program Studi Teknik Informatika, Fakultas Ilmu Komputer, Universitas Brawijaya. 